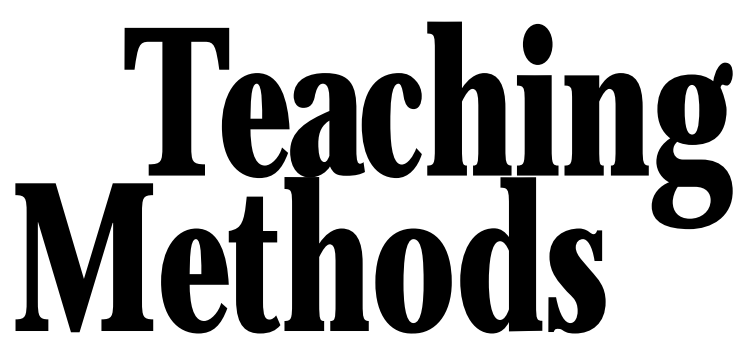

\section{Southwest Home Horticulture: Using Video and the Internet in the Instruction of Nonmajors}

\author{
Chris A. M artin and \\ Jean C. Stutz ${ }^{1}$
}

ADDITIONAL INDEX WORDS. asynchronous, distance learning, urban horticulture, Web site

\begin{abstract}
Summary. A distance learning course called Southwest H ome H orticulture was developed and implemented at Arizona State U niversity using video and Internet technologies to give nonhorticulture students an overview of urban horticulture in the southwestern U nited States. Fourteen, onehalf-hour video programs about topics in southwestern residential landscaping, plants materials and landscape best-management practices were produced in $\approx \mathbf{8 0 0}$ working hours. The video programs are now telecast weekly, each academic semester, on the regional public television station and the educational channel of several cable television systems. We found that students who enrolled in the course were most likely to tape the programs on a video
\end{abstract}

U rban $\mathrm{H}$ orticulture Program, D epartment of Plant Biology, ArizonaStateU niversity, Box 871601 , Tempe, AZ 85287-1601.

The cost of publishing this paper was defrayed in part by the payment of page charges. U nder postal regulations, this paper therefore must be hereby marked advertisement solely to indicate this fact. cassette recorder and watch them at their own convenience, one to three times. A World Wide Web (Web) site on the Internet was developed as a supplement to the video programs. The Web site was organized into a modular format giving students quick access to auxiliary course-related information and helpful resources. When asked, $\approx 90 \%$ of the students indicated that the Web site was a helpful supplement to the video programs. U se of video and Internet technologies in tandem has enabled nonhorticulture major students to learn about home horticulture in an asynchronous or location and time independent fashion.

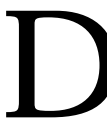

istance learning courses traditionally have been developed to accommodate students remote from university campuses, but increasingly these courses appeal to nontraditional and/ or working students trying to complete their degree programsor upgradetheir education for career advancement (Kennepohl and Last, 1997). Asynchronous delivery of course content that is time and location independent is especially appealing to this segment of the student population at many universities.

A rizonaState U niversity (ASU) is an urban campus located in Tempe, Ariz., where $\approx 42,000$ students are enrolled in daytime and evening classes. The mean age of upper-division undergraduate students at ASU is 25 years old with many of these students employed outside the university. Course offerings that are flexible or meet during evenings or weekends are in high demand by many of these students. The Department of Plant Biology'sU rban H orticultureP rogram in conjunction with ASU's College of
Extended Education developed a new two-credit-hour video course, Southwest $\mathrm{H}$ ome $\mathrm{H}$ orticulture, that satisfies an upper-division general science electiverequirement for thistype of nonscience major undergraduate student. O ur goal throughout the development and implementation of thisnew course was to give nonhorticulture undergraduatestudentsan overview of home horticulture in the southwestern U .S. in a flexible, asynchronous format using video and Internet technologies. The I nternet increasingly functions as an electronic delivery medium for horticultural information ( $D$ avies et al., 1996; Lighter, 1996). U sing the Internet, students enrolled in Southwest $\mathrm{H}$ ome $\mathrm{H}$ orticulture can have quick and repeated access to course-related information supplementing the video portion of the course.

\section{Course description}

Video program deVelopment. Work began on the video portion of the Southwest Home Horticulture course during Summer 1995. Video development activities spanned 18 months and were divided into preproduction, production , and postproduction phases.

D uring the preproduction phase, three participating instructorscollaborated with a video program producer to determine the video program format and the types of programs/ topics to be offered in the course. An important initial decision wasto film most of the video footage under studio conditions because of the high costs associated with on-location filming. A talkshow format was selected, and a parttime production assistant was hired to serve as the on-camera host for each of the video programs.

Fourteen video programs were selected to teach three basic sets of topics in southwestern homehorticulture. The first set focused on southwestern residential landscaping and included programs about landscape design, installation, irrigation and lighting. Principles of landscapewater conservation werean underlying theme for this first set of programs. The second set addressed urban southwestern plant materials and highlighted landscapetrees, shrubs, turfgrasses, citrus, date palms, vegetables, ornamental herbaceous plant materials, including wildflowers, and indoor plants. The third set surveyed southwestern landscape best-management practices 
T able 1. Distribution of working hours required for completion of tasks required for course development.

\begin{tabular}{|c|c|}
\hline $\begin{array}{l}\text { T asks required for } \\
\text { course development }\end{array}$ & $\begin{array}{c}\text { Time needed } \\
\text { (people-hours) }\end{array}$ \\
\hline \multicolumn{2}{|l|}{ Preproduction } \\
\hline D evelopment of content outline and concept formulation & 20 \\
\hline Script development and revisions & 50 \\
\hline Set construction and prop preparation & 56 \\
\hline \multicolumn{2}{|l|}{ Production } \\
\hline In-studio filming & 160 \\
\hline On-location filming & 75 \\
\hline \multicolumn{2}{|l|}{ Postproduction } \\
\hline Editing & 420 \\
\hline Creation of graphics and animation, selection of still image & 42 \\
\hline Study guide and Web page development & 44 \\
\hline
\end{tabular}

and included programs about soil and plant nutrition, pruning, and pest management.

Each participating instructor developed specific program scripts using an interview format in which the instructor served as a guest expert who was interviewed by the program host. Each program opened with a short introduction by the host followed by a question and answer session between the host and the expert instructor. M ost program scripts concluded with a discussion of related topics and used plant material and other demonstration aids to illustrate the instructor's answers to the host's questions. After development, each script wasreviewed by the video program producer who edited the material into a one-half hour program. Additional preproduction activitiesincluded construction of the studio set, plant material acquisition, and preparation of other props need ed for filming. The preproduction phase was completed in 4 months.

The actual production phase was divided into two parts. M ost program content was filmed in-studio during D ecember 1995, and an additional 25 $\mathrm{h}$ of on-location filming occurred during the next 6 months. For example, a short segment on potting media components was videotaped in a greenhouse and used for the soils and plant nutrition program. Postproduction activitiesincluded video editing, creating computer graphicsand animations, and selection of preexisting images for some programs. The postproduction phase was completed in 9 months.

Theentireproduction of the video programsrequired $\approx 800$ working hours (Table 1), with postproduction the dominant activity. Although the ac- tual filming or production phase of the project occurred over the shortest period of time $(4 \mathrm{~d}$ for the in-studio filming plus an additional $25 \mathrm{~h}$ of onlocation filming), this phase involved the most intensive use of personnel. In-studio filming at the ASU College of Extended Education's video production studio required the involvement of six peo ple: the producer, program host, instructor expert, two camera operators and a video/ sound technician. Funding for the entire project was shared by the Colleges of $L$ iberal Arts and Sciences and Extended Education. Participating faculty and staff donated their time.

$U$ pon completion, the video series consisted of 14 one-half-hour videotape programs which were packaged and offered for college credit by ASU for the first time in Spring 1997. Currently, students may access this course as weekly telecasts during the semester on both the regional public television station and on the educational channel of several cable television systems. Videotapes of each program may also beborrowed from ASU 's circulating video library.

Web site development. A Web site on the Internet was developed during the winter and Spring 1997, to supplement the video portion of the course with additional asynchronous learning opportunities between the instructor and student. TheW eb siteismodular in format, providing students with all course-related information and assistance. The central module is the course syllabus and includes instructor information, video telecast schedules, textbook and examination information. To supplement the course syllabus on the Web site, a study guide of review ques- tionsextracted from the video programs was developed for each program. Additionally, five assignments were developed to give students the opportunity to research and report on aspecific topic related to the course. The Web site includes hyperlinks to other pertinent, course-related I nternet sites and can be accessed at http:/ / Is.la.asu.edu/ plantbiology/ syllabus/ plb360.html. Web site maintenance is done by ASU $\mathrm{U}$ rban $\mathrm{H}$ orticulture Program faculty.

Student SURver. In the middle and end of the spring 1998 semester, 50 studentsenrolled in thevideo course wereformally surveyed regarding their impressions of and preferences for the course's video tape and Internet formats. Students were issued the same survey twice in anticipation that their responsesmight changeover the course of thesemester. Student responseswere compiled and correlated to course performance at theend of the spring 1998 semester using PROC FREQ (SAS version 6.03, SAS Inc., Cary, N.C.).

We found no change in student responses to survey question between the middle and end of the semester and no relationship between student responses to any of the questions and their course performance. When asked if this was the first distance learning course they had enrolled in at ASU, $75 \%$ of students responded that it was. Students often taped the video programs for later viewing and watched them one to three times (Fig. 1A-C). When asked about the Internet portion of the course, $\approx 90 \%$ of the students indicated that they found the Web site to be a helpful supplement to the video programs. All students accessed the Web site during the course of the spring semester, and $60 \%$ of students accessed the Web site more than fivetimes. M ost studentsaccessed the Web site from personal computers at home (Fig. 1D). When asked to expressapreference for course delivery format, students unnanimously expressed a preference for a distance learning, multimedia, asynchronous delivery format for this type of course compared with a traditional classroom instruction format.

\section{Conclusion}

Collaboration between faculty in the $\mathrm{U}$ rban $\mathrm{H}$ orticulture Program and staff from the College of Extended Education resulted in the successful development of the Southwest H ome 
$\mathrm{H}$ orticulture course using video and Internet technologies. Students enrolled in the course indicated a high degree of preference for this type of learning approach. Our future plans for this course are to expand the course Web site to include a glossary of terms used on the video programs. We also plan to develop interactive Internet quizzes to aid in the students' mastery of course materials before exams and video streaming modules to highlight key points from each video program.

Student performance and evaluation presented a unique challenge in this type of distance learning course. The absence of a preassigned time and campus location for this class created exam scheduling problems for these nontraditional students. In addition, some students in the course were enrolled at one of ASU's branch campuses and were unable to come to the main ASU campusin Tempe to takean exam. To solve this difficulty, multiple sites in the greater Phoenix area served as designated test centers for these students, and are administered by ASU 's College of Extended Education. Students in the course are required to takethree examinations during the semester and usually do so during evening hours at one of the testing centers. We are currently developing the use of on-line testing.

Since the time that this course was first offered in spring, 1997, $10 \%$ of the nonhorticulturemajor studentsenrolled in the course have expressed an interest in urban horticulture at ASU and have subsequently enrolled in other courses within this program. We now consider this course to be a valuable tool for recruiting students from within ASU into the D epartment of Plant Biology's $\mathrm{U}$ rban $\mathrm{H}$ orticulture Program.

\section{Literature cited}

D avies, G .L., E.F. Gilman, and H .W. Beck. 1996. An electronically based horticulture retrieval system. H ortT echnology 6:332336.

Kennepohl, D. and A.M . Last. 1997. Science at a distance. J. College and Science Teaching 27:35-38.

Lightner, G.A. 1996. Scientific homepages on theW orld WideW eb. H ortT echnology 6:263-265.

Southwest $\mathrm{H}$ ome H orticulture Page. A rizona State U niversity. 23 April 1999 বttp:/ / Is.la.asu.edu/ plantbiology/ syllabus/ PLB360.html>.

Hortlechnology • J uly-September 1999 9(3)

A

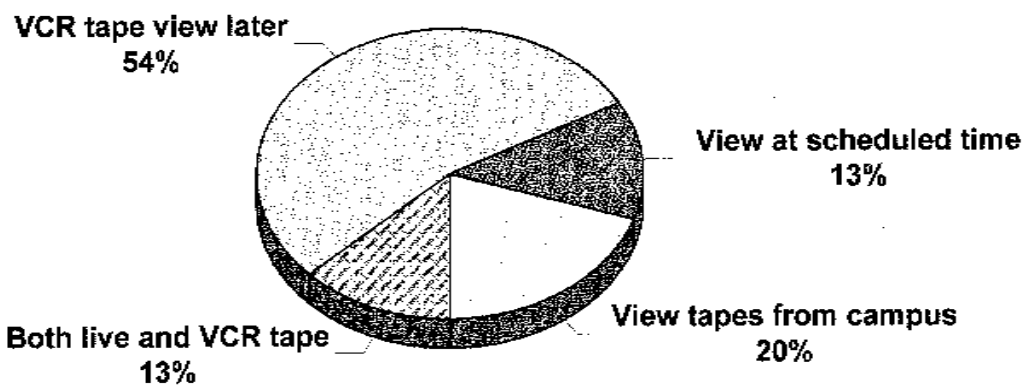

B
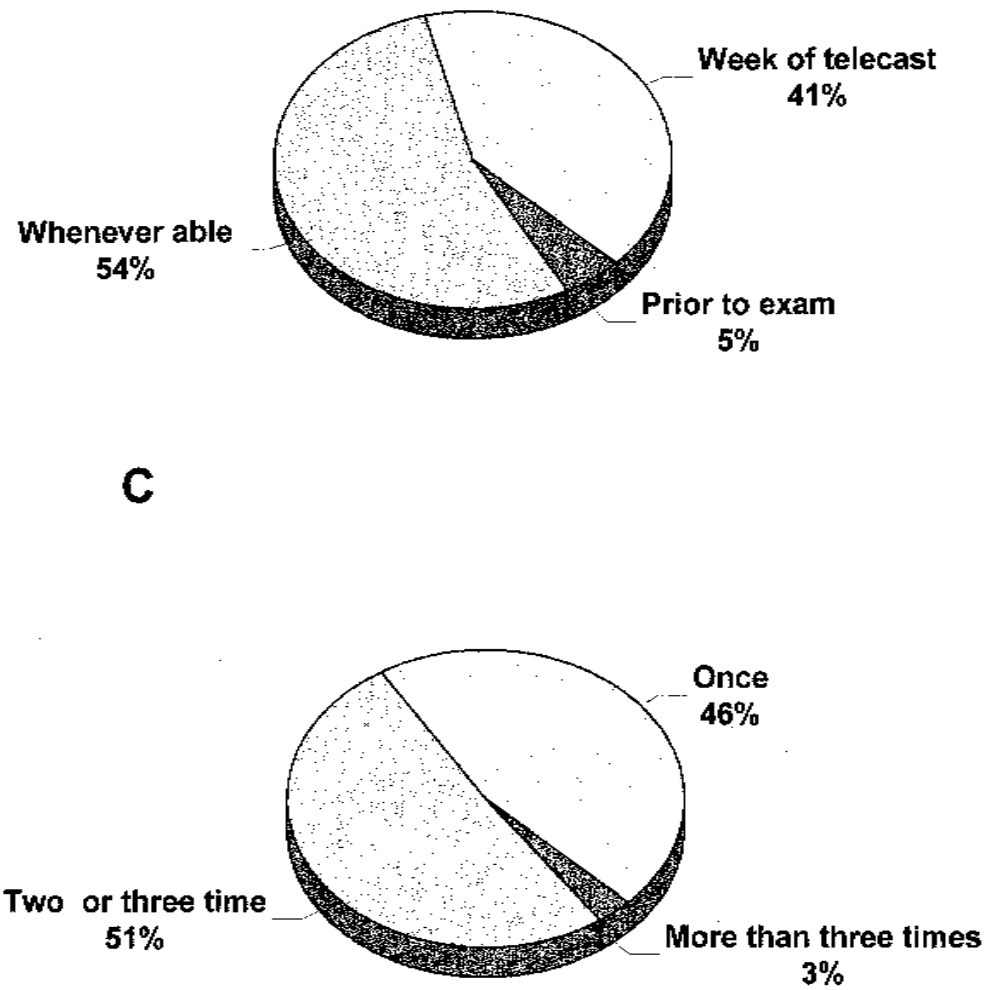

D

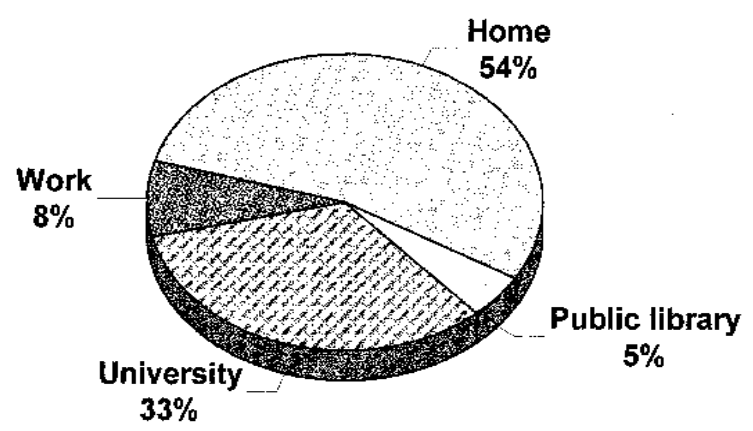

Fig. 1. Student responses to survey questions: (A) Which of the methods below did you most commonly use to view the video programs for the course? (B) When did you typically watch the video programs? (C) H ow often did you typically watch each video program? (D) Where was the Internet W eb site accessed? VC $R=$ video cassette recorder. 